\title{
Production and Partial Characterization of Cellulase from Pseudomonas Isolates Obtained from Cow Dung and Municipal Solid Wastes
}

\author{
Md. Mehadi Hasan Sohag ${ }^{1}$, Md. Mahbub Hasan ${ }^{1}$, Jahed Ahmed ${ }^{1}$, Syed Nur Ahmed Daud ${ }^{1}$, Md. Khurshid Alam¹, \\ Mohammad Ruhul Amin², Md. Mozammel Hoq ${ }^{3}$ and Abul Kalam Azad ${ }^{1, *}$ \\ ${ }^{1}$ Department of Genetic Engineering and Biotechnology, Shahjalal University of Science and Technology, Sylhet-3114, Bangladesh, ${ }^{2}$ Department of \\ Microbiology, Noakhali Science and Technology University, Sonapur, Noakhali-3814, Bangladesh, ${ }^{3}$ Department of Microbiology, University of Dhaka, \\ Dhaka-1000, Bangladesh
}

\begin{abstract}
Cellulase producing bacteria were isolated from cow dung and municipal solid wastes using enrichment technique. Cellulase activity was determined on carboxymethyl cellulose (CMC) agar medium supplemented with 1\% CMC. Production of clear zones by the bacterial isolates on CMC agar was considered as indicative of extracellular cellulase activity. The greater size of transparent zone diameter was found proportional to the higher amount of cellulase production. Two bacterial isolates producing significant clear zone were identified as Pseudomonas spp based on morphological, cultural and biochemical characteristics. Fermentation was carried out under shake flask conditions for production of cellulase from Pseudomonas isolates in a basal medium containing $\mathrm{CMC}, \mathrm{KH}_{2} \mathrm{PO}_{4}, \mathrm{~K}_{2} \mathrm{HPO}_{4}, \mathrm{MgSO}_{4}, \mathrm{NH}_{4} \mathrm{SO}_{4}, \mathrm{CaCl}_{2}$ and $\mathrm{FeSO}_{4}$ at $\mathrm{pH}$ 7.0. The assay of cellulase viz. endoglucanase and exoglucanase in terms of CMCase and FPase, respectively was done by measuring the release of the reducing sugar. Some parameters influencing the production of cellulase by these bacterial isolates were investigated. Optimum level of cellulase was produced after $\mathbf{4 8} \mathrm{h}$ of fermentation at $37^{\circ} \mathrm{C}$ with $5 \%$ inoculums size under continuous agitation at $120 \mathrm{rpm}$ in the growth medium of $\mathbf{p H} 7.0$. Optimum temperature and $\mathrm{pH}$ for the activity of cellulase from these bacterial isolates was $40^{\circ} \mathrm{C}$ and 7.0 , respectively. Cellulase from these isolates was found almost stable at $25-40^{\circ} \mathrm{C}$ and $\mathrm{pH}$ 6.0-8.0 for $1 \mathrm{~h}$. Furthermore, the cellulase activity was stimulated by $\mathrm{Ca}^{2+}$ and $\mathrm{K}^{+}$but inhibited by $\mathrm{Hg}^{2+}$ and $\mathrm{Zn}^{2+}$, whereas, $\mathrm{Mg}^{2+}$ showed very low effect. Results reported herein indicated that the Pseudomonas isolates can be used as producer of extracellular cellulase.
\end{abstract}

Keywords: Carboxymethyl cellulose, cellulase, CMCase, municipal solid wastes, Pseudomonas spp.

\section{Introduction}

As the major component of plant biomass, cellulose is a linear polymer which consists of 8000-12000 glucose units that are linked through 1, 4- $\alpha$-D-glycosidic bonds ${ }^{1}$. Biosynthesis of cellulose by both plants and marine algae at a rate of $8.5 \times 10^{11}$ tons per annum ensures that it is the earth's most abundant polysaccharide and an inexhaustible source of renewable bio energy ${ }^{2-3}$. The collective term of cellulase "Cellulosomes" are combinatorial term for multiprotein complex that contains endoglucanase or 1,4-âD-glucan-4-glucanohydrolases (EC 3.21.4), exoglucanase including 1,4-D-glucan glucanohydrolases (EC 3.2.1.74), cellobiohydrolase or 1,4- $\beta$-D glucan cellobiohydrolases (EC 3.2.1.91) and $\beta$-glucosidase or $\beta$-glucoside glucohydrolases or cellobiase (EC 3.2.1.21) ${ }^{4}$. Cellulases are inducible enzymes and the regulation of cellulase production is finely controlled by activation and repression mechanisms ${ }^{5}$. Cellulases have applications in fermentable sugars and ethanol production ${ }^{6}$, textile industry ${ }^{7}$, household laundry and detergent ${ }^{8-9}$, animal feed ${ }^{10}$, brewery and wine as well as in pulp and paper industries ${ }^{11}$. Currently, cellulases are not produced commercially in Bangladesh and tons of cellulases are imported every year to use in different industries. A plenty of microorganisms are inevitably responsible to produce cellulases. Though the most common producer being the fungi, cellulase production has been reported earlier in various microbial systems like fungi, bacteria ${ }^{12}$ or actinomycetes ${ }^{13}$. Bacteria are now widely exploited because of high growth rate and short generation time compared to fungi ${ }^{14}$, 15. The greatest potential importance is the ease with which bacteria can be genetically engineered. This is needed especially in order to enhance cellulase production ${ }^{16}$.

About 7,690 tons of municipal solid wastes (MSW) are generated daily at the six major cities of Bangladesh namely, Dhaka, Chittagong, Rajshahi, Khulna, Barishal and Sylhet which may be increased up to 47,000 tons per day by 2025 due to increase in population and urbanization ${ }^{17-18}$. About $75-85 \%$ constituents of the MSW is organic and approximately $80 \%$ of this organic content is cellulosic which can be utilized as raw materials for cellulase production. Currently, MSW in Bangladesh are generally collected and dumped in low lands or disposed haphazardly causing environmental pollution and public health hazards ${ }^{19}$. 
Methane gas is emitted from the rotten MSW. Methane is the second potent greenhouse gas having 20 times more impact on climate change compared to the carbon dioxide. Therefore, cellulosic biomass of MSW needs to be bioconverted into bioresources through production of value added products such as enzymes. Cellulase can be produced by bacteria using cellulosic MSW as the raw material. With this view, we herein isolated and screened cellulase producing bacterial isolates from MSW and cow dung and optimized some parameters for cellulase production. Cellulases produced from these bacterial isolates were partially characterized.

\section{Materials and Methods}

Isolation and identification of cellulase-producing bacterial isolates

Cow dung samples were collected from Baghbari Slaughtering House, Sylhet City Corporation, Bangladesh immediately after slaughtering the cow. Cellulosic MSW samples were collected from the dustbin at Rikabi Bazar of Sylhet City Corporation, Bangladesh. One gram of the sample was suspended in $9 \mathrm{ml}$ of sterile distilled water. After a serial dilution of this suspension $\left(10^{1}\right.$ to $10^{6}$ times), $200 \mu \mathrm{l}$ from each dilution was spread onto carboxymethyl cellulose (CMC) agar (1.0\% CMC, $0.4 \%$ yeast extract, $0.5 \%$ malt extract, $1.2 \%$ agar; $\mathrm{pH} 7.0$ ) plates and incubated at $37^{\circ} \mathrm{C}$ for $24-48 \mathrm{~h}$. Fifty isolated bacterial colonies from each type of samples were randomly selected and purified onto the same media with two replicas to investigate their cellulolytic activity. After $24 \mathrm{~h}$ of incubation under the same condition, one replica plate was flooded with Gram's iodine solution. Bacteria showing a clear zone due to hydrolysis of CMC were selected as cellulase producers. The ratio of diameter of the clear zone to bacterial colony was measured in order to select the efficient cellulase producer and the ratio of 5 was chosen as significant. The corresponding colonies that produced the ratio of clear zone 5 or more were considered to have higher cellulase activity and were selected from another culture plate for further studies. The bacterial isolates selected as cellulase producers were identified based on cultural, morphological and various biochemical characteristics as described in Bergey's Manual of Systematic Bacteriology ${ }^{20}$.

\section{Cellulase production}

A basal media $\left(0.1 \% \mathrm{KH}_{2} \mathrm{PO}_{4}, 0.1 \% \mathrm{~K}_{2} \mathrm{HPO}_{4}, 0.04 \% \mathrm{MgSO}_{4}, 0.5 \%\right.$ $\mathrm{NH}_{4} \mathrm{SO}_{4}, 0.005 \% \mathrm{CaCl}_{2}, 0.000125 \% \mathrm{FeSO}_{4}, 1 \% \mathrm{CMC} ; \mathrm{pH} 7.0$ ) was used for production of cellulase unless noted. For seed culture, a fresh isolated colony was inoculated in $5 \mathrm{ml}$ basal media and incubated at $37^{\circ} \mathrm{C}$ and $120 \mathrm{rpm}$ for $24 \mathrm{~h}$. The seed culture $(2.5 \mathrm{ml})$ was then inoculated in $47.5 \mathrm{ml}$ of the same media in a $250 \mathrm{ml}$ conical flask and incubated at the conditions as indicated. The cell free supernatant obtained by centrifugation at 5,000 rpm for 15 min at $4{ }^{\circ} \mathrm{C}$ was used for determining the cellulase activity or for further study.

Carboxymethyl cellulase (CMCase) activity for endoglucanase The CMCase activity was assayed using a method described by Wood and Bhat ${ }^{21}$. In brief, $0.2 \mathrm{ml}$ of cell free supernatant was added to $1.8 \mathrm{ml}$ of $1 \%$ CMC prepared in $50 \mathrm{mM}$ sodium citrate buffer (pH 6.0) and incubated for $30 \mathrm{~min}$ at $40{ }^{\circ} \mathrm{C}$. The reaction was terminated by adding $3.0 \mathrm{ml}$ of $1 \%$ (w/v) dinitrosalicylic acid (DNS) reagent and by subsequent exposing at $100^{\circ} \mathrm{C}$ for $15 \mathrm{~min}$. One $\mathrm{ml}$ of Rochelle salt solution (40 gm Rochelle salt in $100 \mathrm{ml}$ distilled water) was then added to stabilize the color. The absorbance was recorded at $575 \mathrm{~nm}$ using UV-visible spectrophotometer (model-T60U, PG Instruments Ltd, England). One unit of CMCase activity was expressed as $1 \mu$ mole of glucose liberated per ml enzyme per minute. For negative control, $1 \%(\mathrm{w} / \mathrm{v})$ DNS solution was added before addition of cell free supernatant.

\section{Filter paper activity (FPase) for exoglucanase}

The FPase activity was assayed according to the method described by Wood and Bhat ${ }^{21}$. Whatman no.1 filter paper strip $(1 \times 3 \mathrm{~cm})$ was soaked in $1.8 \mathrm{ml} 50 \mathrm{mM}$ sodium citrate buffer $(\mathrm{pH}$ 6.0). Then $0.2 \mathrm{ml}$ of cell free supernatant was added to it and was incubated at $40^{\circ} \mathrm{C}$ for $60 \mathrm{~min}$. The reaction was terminated as described above and the absorbance at $575 \mathrm{~nm}$ was measured. One unit of FPase activity was determined as $1 \mu$ mole of glucose liberated per ml enzyme per minute.

\section{Optimization of cultivation period for cellulase production}

To determine the optimum cultivation period for maximum cellulase production, the seed culture was inoculated into the media as described above and incubated at $37^{\circ} \mathrm{C}$. During fermentation, samples of the culture were withdrawn aseptically with $6 \mathrm{~h}$ intervals to investigate the level of CMCase and FPase activity and the bacterial growth.

Investigation for optimum cultivation temperature and initial $\mathrm{pH}$ of the culture media for cellulase production

To obtain the optimum temperature for cellulase production, fermentation was done at $25,30,35,37,40$ and $45^{\circ} \mathrm{C}$ with continuous agitation at $120 \mathrm{rpm}$. The initial $\mathrm{pH}$ of the media was adjusted to 7.0. In order to investigate the influence of $\mathrm{pH}$ on the production of cellulase, the initial $\mathrm{pH}$ of the basal media was adjusted to 4.0-9.0 as indicated. The fermentation was carried out at $37^{\circ} \mathrm{C}$ and $120 \mathrm{rpm}$ for $48 \mathrm{~h}$.

\section{Effects of agitation on cellulase production}

To determine the effects of agitation rates on the production of cellulase, fermentation was carried out under different agitation rates as indicated at $37^{\circ} \mathrm{C}$. The initial $\mathrm{pH}$ of the culture media was adjusted to 7.0 .

\section{Effects of temperature and $\mathrm{pH}$ on cellulase activity and stability}

To investigate the effects of temperature on cellulase activity, CMCase assay was performed at $25-45^{\circ} \mathrm{C}$ for $30 \mathrm{~min}$. The thermo stability of cellulase was studied by incubating the crude cellulase preparation at different temperatures as indicated for $1 \mathrm{~h}$. The residual CMCase activities were then assayed to evaluate the heat stability. 
Effects of $\mathrm{pH}$ on cellulase activity were observed by conducting cellulase assay with $50 \mathrm{mM}$ buffers of different $\mathrm{pH}$ (4.0 to 9.0) in which $1 \%$ CMC solutions were prepared. The $\mathrm{pH}$ stability of cellulase was studied as described previously ${ }^{22}$. Each $1 \mathrm{ml}$ of crude cellulase was treated for $1 \mathrm{~h}$ with $1 \mathrm{ml}$ of different buffers covering the range of $\mathrm{pH} 4.0$ to 9.0. Residual CMCase activities were assayed as described above.

\section{Effects of metal ions on cellulase activity}

To determine the effects of metal ions on the activity of crude cellulase, $500 \mu \mathrm{l}$ of enzyme preparation was treated with $500 \mu \mathrm{l}$ of 10 $\mathrm{mMCaCl}, \mathrm{KCl}, \mathrm{MgCl}_{2}, \mathrm{HgCl}_{2}$ or $\mathrm{ZnCl}_{2}$ for $1 \mathrm{~h}$ at room temperature. Following the treatment, the CMCase activity was determined as described above. Relative activities were expressed as a percentage of the activity of the untreated control taken as 100\%.

\section{Statistical analysis}

For statistical analysis, Student's t test was used. Ap value of $<0.05$ was considered to be statistically significant. Data were presented as the means \pm standard errors of the means (SEM) of at least three independent experiments, or as noted in the figure legends.

\section{Results and Discussion}

\section{Isolation and identification of bacterial isolates}

Cellulolytic bacteria were isolated from the MSW and cow dung following the method described by Hankin and Anagnostakis ${ }^{23}$ using a media which contained CMC as the carbon source. Using of CMC as a source of carbon plays a pivotal role for achieving the highest level of cellulase production because CMC induces cellulase expression ${ }^{13,23-24}$. Isolated bacterial colonies with higher cellulase activity were further screened to obtain the pure culture. The pure culture produced clear zone when it was flooded with Gram's iodine solution due to hydrolysis of CMC (Figure 1). Gram's iodine forms a bluish-black complex with cellulose but not with hydrolyzed cellulose, giving a sharp and distinct zone around the cellulase-producing bacterial colonies within 3 to 5 minutes. Clear zone producing bacterial isolates were then subjected to various morphological, cultural and biochemical tests. Based on morphological and cultural characteristics and the results of biochemical tests, bacterial isolate 6 from MSW and isolate 32 from cow dung were identified as Pseudomonas sp. (Table 1).

Table 1. Morphological, cultural and biochemical characteristics of bacterial isolates

\begin{tabular}{lcc}
\hline $\begin{array}{l}\text { Morphological, cultural and } \\
\text { biochemical tests }\end{array}$ & Isolate 6 & Isolate 32 \\
\hline Shape & Rod & Rod \\
Colony color on nutrient agar & Greenish & Greenish \\
Motility test & + & + \\
Growth in air & + & + \\
Catalase test & + & + \\
Oxidase test & + & + \\
Gram staining & - & - \\
Spore test & - & - \\
Methyl-Red test & - & - \\
Voges-Proskauer test & - & Pseudomonas sp. \\
Name of genus of bacteria & Pseudomonas sp. Pomorat
\end{tabular}

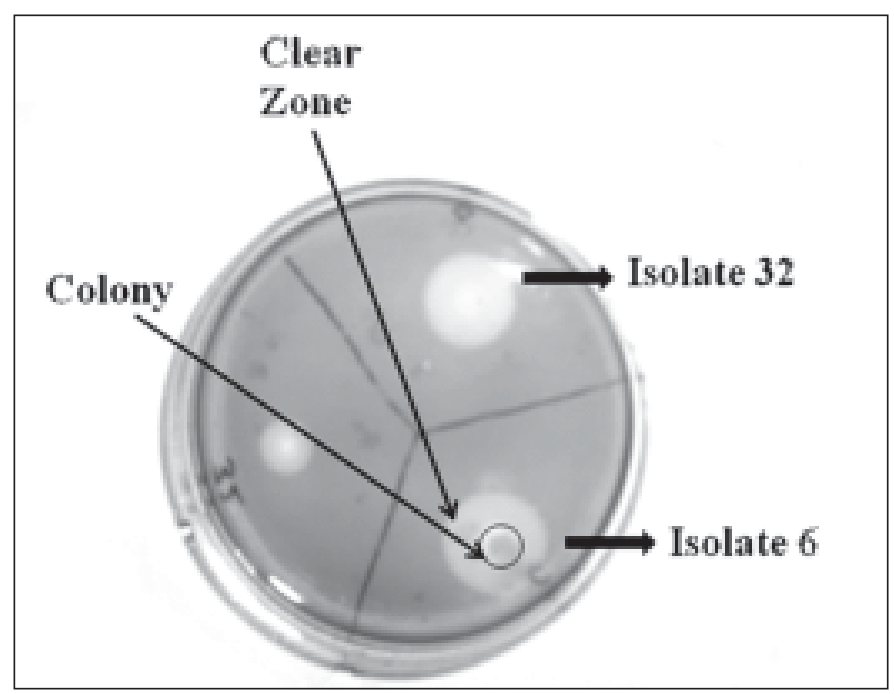

Figure 1. Visualization of cellulase activity with Gram's iodine solution. Cellulolytic bacteria were screened from the master plate to obtain pure culture. Isolate 6 taken from MSW sample and Isolate 32 taken from cow dung are indicated. Cellulolytic activity was observed on CMC agar media after incubation at $37^{\circ} \mathrm{C}$ for $24 \mathrm{~h}$. A typical result of three independent experiments for cellulolytic bacteria on CMC agar media is shown.

\section{Fermentation conditions for cellulase production}

Fermentation period, cultivation temperature, initial $\mathrm{pH}$ of the culture media and agitation are the most striking features to influence the production of enzymes ${ }^{25-26}$. Time course study revealed that the fermentation period for optimum production of cellulase by the both isolates was $48 \mathrm{~h}$ with $5 \%$ inoculums size (Figure 2). Cellulolytic bacterial isolates from the Persian Gulf showed their optimal production of cellulase after $48 \mathrm{~h}$ of cultivation $^{13}$. However, optimum cultivation period varies from strain to strain with their characteristics and cultural conditions ${ }^{27}$. Figure 2 showed that isolate 32 produced approximately 15\%

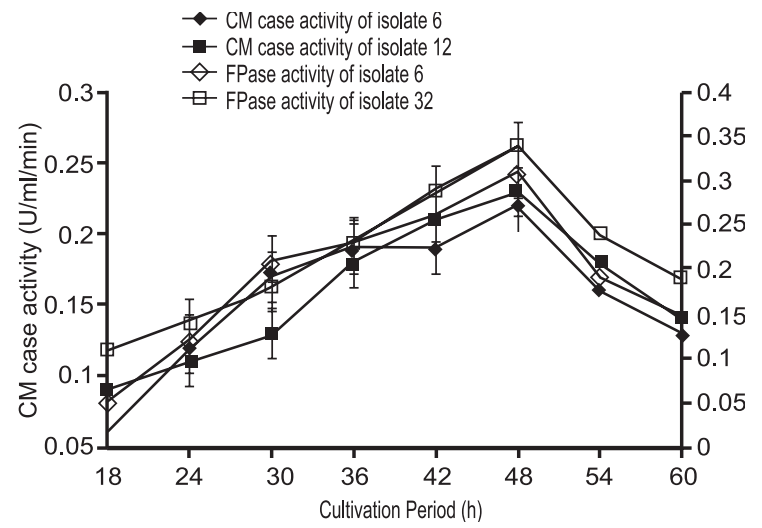

Figure 2. Time course for cellulase production. The fermentation at shake flask was carried out at $37^{\circ} \mathrm{C}$ and $120 \mathrm{rpm}$ with $5 \%$ inoculums size. The initial $\mathrm{pH}$ of the media was adjusted to 7.0. CMCase and FPase activities were determined at $6 \mathrm{~h}$ interval during fermentation. 
higher level of cellulase compared to isolate 6 based on CMCase and FPase activities. Nevertheless, cellulase production level by these two isolates was growth associated (data not shown). For further investigations in the subsequent experiments, we used only CMCase assay. In all of the experiments for production of cellulase, $5 \%$ inoculum was used because this inoculum size was found to produce maximum level of cellulase (data not shown).

We optimized the cultivation temperature as it had profound effects on production of enzyme by bacteria ${ }^{28}$. The optimum temperature for maximum production of cellulase by the both isolates was $40^{\circ} \mathrm{C}$ although a considerable level of cellulase was produced at $35^{\circ} \mathrm{C}$ (Figure 3). The level of cellulase produced by the both isolates at $37^{\circ} \mathrm{C}$ was almost the same as was found at 40 ${ }^{\circ} \mathrm{C}$ (data not shown). In this experiment, isolate 6 produced about $10 \%$ higher level of cellulase compared to isolate 32 at $40^{\circ} \mathrm{C}$. Figure 3 further showed that the level of cellulase produced by the both isolates at $30^{\circ} \mathrm{C}$ and $45^{\circ} \mathrm{C}$ was approximately $50 \%$ compared to that at $40^{\circ} \mathrm{C}$. However, temperature optima for cellulase production may vary from species to species of bacteria $^{29-30}$.

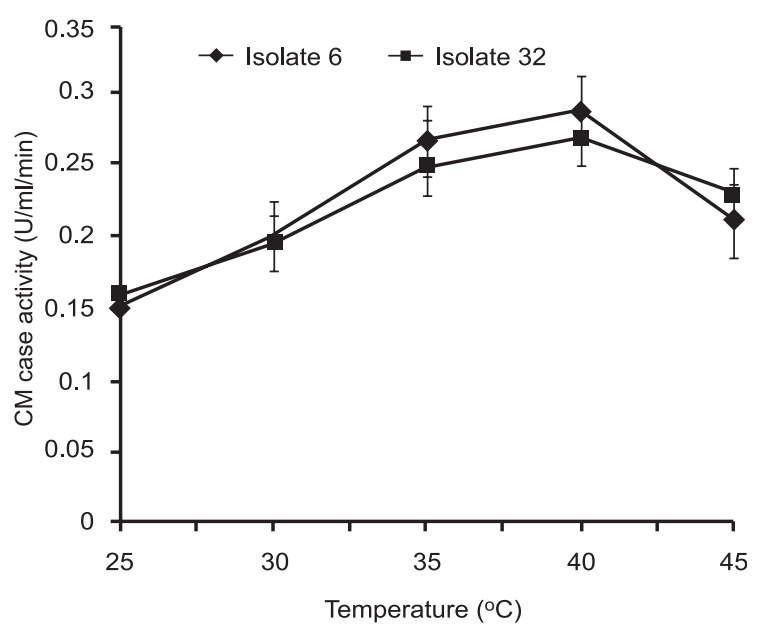

Figure 3. Effects of cultivation temperature on cellulase production. Fermentation was done at temperature as indicated at $120 \mathrm{rpm}$ for $48 \mathrm{~h}$. The initial $\mathrm{pH}$ of the culture media was adjusted to 7.0. The level of cellulase at $37^{\circ} \mathrm{C}$ was not shown as it was almost the same as at $40^{\circ} \mathrm{C}$.

The cellulase production by bacterial isolates is controlled by the extracellular $\mathrm{pH}$ as the $\mathrm{pH}$ of the culture media strongly influences many enzymatic processes. We investigated the effects of initial $\mathrm{pH}$ of the media on the production of cellulase by the two bacterial isolates. It was found that the optimum $\mathrm{pH}$ for cellulase production by the both isolates was 7.0 (Figure 4). However, significant levels (approximately $60-70 \%$ of the peak levels) of cellulase production by Pseudomonas spp were supported by $\mathrm{pH}$ range between 6.0 and 8.0. This result indicated that the optimum level of cellulase from Pseudomonas isolates was secreted at neutral $\mathrm{pH}$. It was previously reported that cellulolytic bacteria produced highest level of cellulase at a $\mathrm{pH}$ range of $6 \cdot 0-7 \cdot 5^{15,30}$.

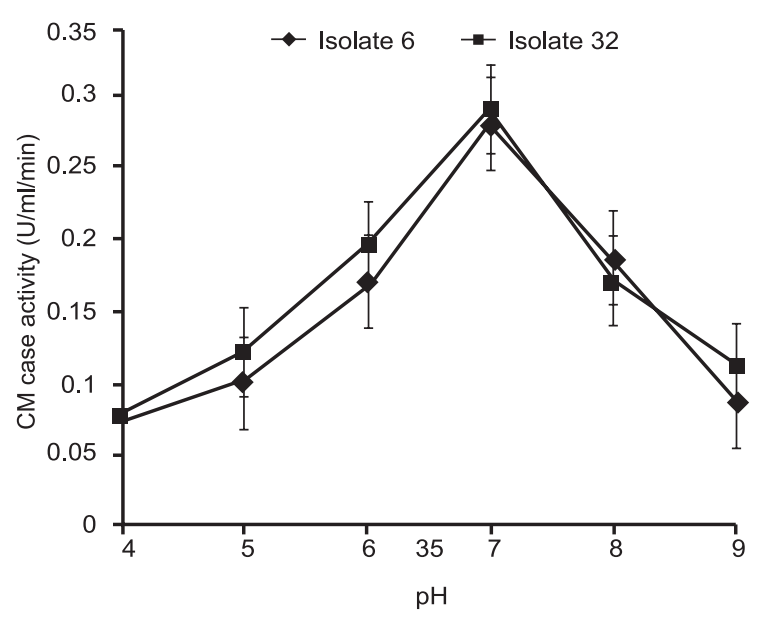

Figure 4. Effects of initial $p H$ of the media on cellulase production. The initial $\mathrm{pH}$ of the culture media was adjusted as indicated and the fermentation was carried out at $37^{\circ} \mathrm{C}$ and $120 \mathrm{rpm}$ for $48 \mathrm{~h}$.

Agitation rates have marked effects on dissolved oxygen in fermentation vessel and thereby on the bacterial growth and enzyme production. The effect was investigated through three independent experiments carried out at 110, 120 and $130 \mathrm{rpm}$ under optimum cultivation temperature and initial $\mathrm{pH}$ of the culture media for $48 \mathrm{~h}$ (Figure 5). Figure 5 showed that the maximum level of cellulase production was favored at 120 rpm compared to at 110 and $130 \mathrm{rpm}$. Oxygen limitation might have slowed down the growth rate and thus the cellulase production at $110 \mathrm{rpm}$ and higher shear force at $130 \mathrm{rpm}$ might have caused cell disintegration leading to lower level of cellulase production.

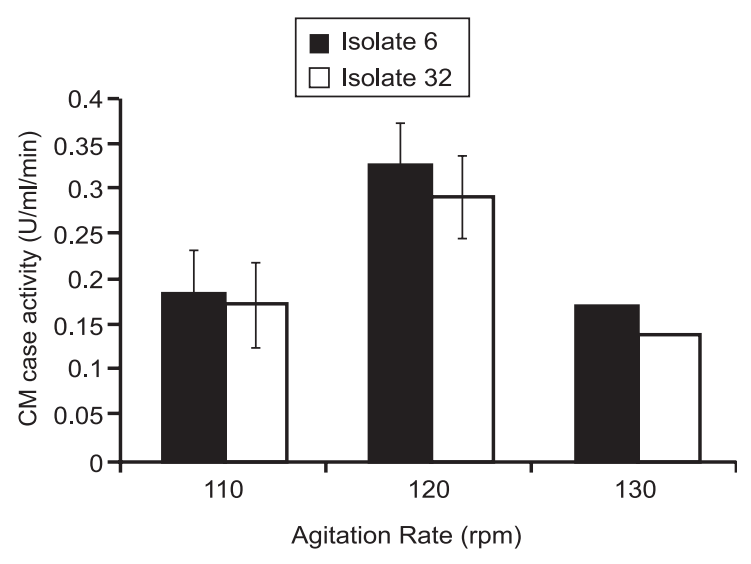

Figure 5. Effects of agitation rates on cellulase production. The initial $p H$ of the culture media was adjusted to 7.0. Fermentation was performed at $37^{\circ} \mathrm{C}$ for $48 \mathrm{~h}$ under continuous agitation as indicated. 


\section{Partial characterization of cellulase}

It is necessary to optimize the physicochemical conditions for maximum activity of an enzyme before its application. In this study, we determined the optimum temperature and $\mathrm{pH}$ for the activity of cellulase produced by the both Pseudomonas isolates. We further investigated the stability of this cellulase by treating it under a wide range of temperatures and $\mathrm{pH}$ as well as the effects of different metallic ions on cellulase activity.

Temperature has marked effect on the activities of enzymes ${ }^{31}$. We determined that the optimum temperature for the cellulolytic activity of cellulase secreted by the both bacterial isolates in this study was $40^{\circ} \mathrm{C}$ (Figure 6). At $35^{\circ} \mathrm{C}$, the activity of cellulase from the both isolates was approximately $75 \%$ in comparison with that at $40^{\circ} \mathrm{C}$. However, only $40 \%$ cellulase activity was observed at 30 and $45^{\circ} \mathrm{C}$ (Figure 6). Amore et al ${ }^{14}$ depicted that the highest activity of cellulase was found at $40^{\circ} \mathrm{C}$ which was similar to our study. Cellulases from the both Pseudomonas isolates was almost stable at $25-40^{\circ} \mathrm{C}$ for $1 \mathrm{~h}$ (Figure 6), which was in agreement with the cellulase from Bacillus amyloliquefaciens B31C strain ${ }^{14}$. Nevertheless, about $30 \%$ of the cellulase activity was lost when the crude enzyme was treated at $45^{\circ} \mathrm{C}$.
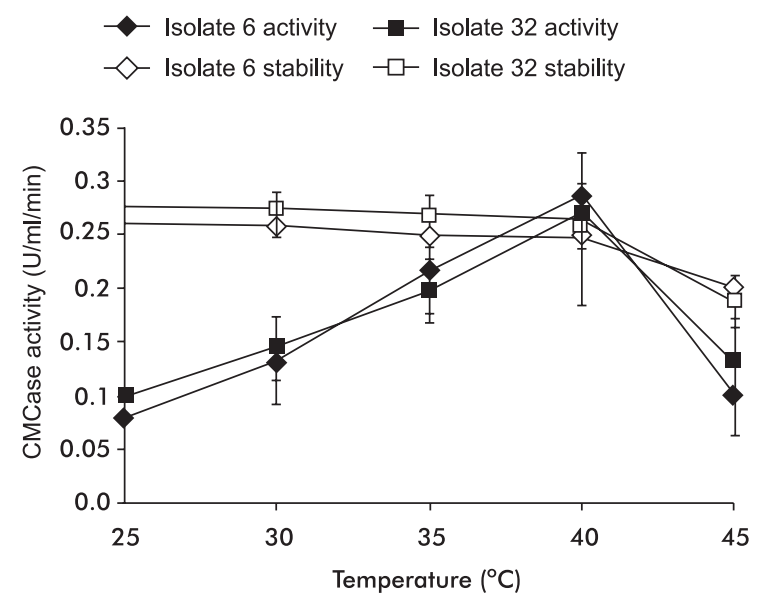

Figure 6. Effects of temperature on cellulase activity and stability.

The effects of $\mathrm{pH}$ on cellulase activity were investigated using $\mathrm{CMC}$ in $50 \mathrm{mM}$ buffer solution with $\mathrm{pH}$ ranging from 4.0-9.0. The optimum cellulase activity was found at neutral $\mathrm{pH}$ (Figure 7) which was close to the optimal $\mathrm{pH}$ value of most bacterial cellulases ${ }^{26}$. Approximately $85 \%$ of the optimum activity was found at $\mathrm{pH} 6.0$ and 8.0. However, cellulase from fungi shows the highest activity at acidic $\mathrm{pH}^{9}, 32$. We also examined the $\mathrm{pH}$ stability of the crude cellulase by treating it with buffer solutions of different $\mathrm{pH}$. The cellulase in our study was almost stable for $1 \mathrm{~h}$ at $\mathrm{pH}$ 6.0-8.0. However, cellulase activity was significantly lost when it was treated under $\mathrm{pH} 6.0$ or 9.0 and cellulase from fungal source was unstable at alkaline condition ${ }^{9}$.

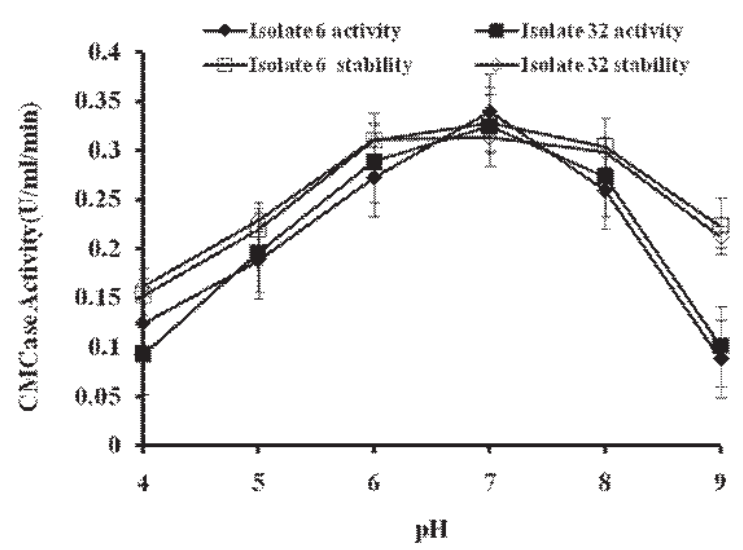

Figure 7. Effects of $\mathrm{pH}$ on cellulase activity and stability. For pH 4.0-6.0, $50 \mathrm{mM}$ sodium citrate buffer was used and $50 \mathrm{mM}$ Tris-HCl was used for $\mathrm{pH}$ 7.0-9.0.

Metal ions are known to play pivotal role as cofactors for enzyme activities, and form salt or ion bridges between or among amino acid residues. In the present study, the crude enzyme preparation was treated by five metal ions to investigate the activation or inhibition effects (Table 2). Results showed that the activity of cellulase from the both isolates increased approximately 15-30\% in the presence of $\mathrm{Ca}^{2+}$ and $\mathrm{K}^{+}$as compared to the control. $\mathrm{Mg}^{2+}$ had low effect on the enzyme activity. On the other hand, the enzyme activity of the both isolates decreased approximately 35$40 \%$ in the presence of $\mathrm{Hg}^{2+}$ and about $25-30 \%$ in the presence of $\mathrm{Zn}^{2+}$. However, different metal ions have different effects on cellulase activity and the activation and/or inhibition effects depend even on the concentrations of metal ions ${ }^{33}$.

Table 2: Effects of different metal ions on the CMCase activity of the both bacterial isolates

\begin{tabular}{lcc}
\hline Metal ion $^{\mathrm{a}}$ & \multicolumn{2}{c}{ CMCase activity $(\%)^{\mathrm{b}}$} \\
\cline { 2 - 3 } & \multicolumn{1}{c}{ Isolate 6 } & Isolate 32 \\
\hline Control (None) & 100 & 100 \\
$\mathrm{Mg}^{2+}$ & $105 \pm 4$ & $103 \pm 3$ \\
$\mathrm{Ca}^{2+}$ & $115 \pm 5$ & $128 \pm 5$ \\
$\mathrm{Hg}^{2+}$ & $62 \pm 3$ & $65 \pm 3$ \\
$\mathrm{Zn}^{2+}$ & $70 \pm 3$ & $74 \pm 3$ \\
$\mathrm{~K}^{+}$ & $127 \pm 6$ & $116 \pm 4$ \\
\hline
\end{tabular}

aThe concentration of metal ions was $5 \mathrm{mM}$.

${ }^{b}$ Data are mean \pm SEM of three independent experiments.

\section{Conclusion}

The present study has isolated two cellulolytic bacteria that have been identified as Pseudomonas spp based on morphological, cultural and biochemical characteristics. Some parameters such as fermentation period, cultivation temperature, initial $\mathrm{pH}$ of the culture media, and agitation rates during fermentation have been optimized for production of cellulase by these two bacterial isolates. Moreover, the crude cellulase of the both bacterial isolates has been characterized in terms of effects of temperature 
and $\mathrm{pH}$ on the CMCase activity and stability. In addition, the CMCase activity of the crude enzyme has been characterized based on the activation and/or inhibition effects of some metal ions. Currently we are performing scale-up of the cellulase production by these bacterial isolates in the bioreactor (Fermac 320, Electrolab, UK) by using cellulosic MSW for purification, molecular characterization and application of the cellulase.

\section{Acknowledgements}

The work was supported by a grant-in-aid from the Ministry of Science and Technology, Bangladesh (No. 39.009.006.01.00.042.2012-13/BS-135/518), the World Academy of Sciences (TWAS) (No. 12-150 RG/BIO/AS_G) and research grant from Shahjalal University of Science and Technology, Sylhet3114, Bangladesh

\section{References}

1. Andrade JP, Bispo ASR, Marbach PAS, do Nascimento RP. 2011. Production and partial characterization of cellulases from Trichoderma sp. is-05 isolated from sandy coastal plains of northeast Brazil. Enz. res. 2011:7.

2. Rathnan RK, Gopal S, Thomas M, Antony S, Thomas C, Mechoor A. 2012. Effective utilization of an aquatic weed salvinia molesta as a substarte for the production of cellulase enzyme-eradication through utilization. Intern. J. of Environ. Sci.3(1).

3. Ja'afaru MI, Fagade OE. 2010. Optimization studies on cellulase enzyme production by an isolated strain of Aspergillus niger YL128. Afr. J. Microbiol. Res.4(24):2635-2639.

4. Glick B. Pasternak J. (2003). Molecular Biotechnology-Principle and Appliation of Recombinant DNA. $3^{\text {rd }}$ Ed, ASM Press, USA.

5. Sukumaran RK, Singhania RR, Pandey A. 2005. Microbial cellulasesproduction, applications and challenges. J. of Scient. and Indus. Res.64(11):832.

6. Galbe M, Zacchi G (2002). A review of the production of ethanol from softwood. Appli. microbio. and biotechn.59(6):618-628.

7. Duran N, Duran M. 2000. Enzyme applications in the textile industry. Rev. of Progr. in Colorat. and Relat. Topics.30(1):41-44.

8. Kirk O, Borchert TV, Fuglsang CC. 2002. Industrial enzyme applications. Curr. opin. in biotechn.13(4):345-351.

9. Hanumasri M, Sudhakar P. 2011. Isolation of cellulase producing fungi from soil, optimization and molecular characterization of the isolate for maximizing the enzyme yield. World J. of Sci. and Techn.1(5).

10. Chesson A. 1987. Supplementary enzymes to improve the utilization of pig and poultry diets. Rec. adv. in animal nutri.

11. Gomes J, Steiner W. 2004. The biocatalytic potential of extremophiles and extremozymes. Food techn. and Biotechn.42(4):223-235.

12. Irwin DC, Zhang S, Wilson DB. 2000. Cloning, expression and characterization of a family 48 exocellulase, Cel48A, from Thermobifida fusca. Eur. J. Biochem.267(16):4988-4997.

13. Samira M, Mohammea R, Gholamreza G. 2011. Carboxymethylcellulase and filter-paperase activity of new strains isolated from Persian Gulf. Microbio. J.1(1):8-16.

14. Amore A, Pepe O, Ventorino V, Birolo L, Giangrande C, Faraco V. 2013. Industrial waste based compost as a source of novel cellulolytic strains and enzymes. FEMS microbio. letters.339(2):93-101.

15. Otajevwo F, Aluyi H. 2011. Cultural conditions necessary for optimal cellulase yield by cellulolytic bacterial organisms as they relate to residual sugars released in broth medium. Modern Appl. Sci.5(3).
16. Ariffin H, Abdullah N, Umi Kalsom M, Shirai Y, Hassan M. 2006. Production and characterization of cellulase by Bacillus pumilus EB3. Intern. J. of Eng. and Techn.3(1):47-53.

17. Alamgir M, Ahsan A. 2007. Municipal solid waste and recovery potential: Bangladesh perspective. Iranian J. of Environ. Health Sci. \& Eng.4(2).

18. Bahauddin K, Uddin M. 2012. Prospect of solid waste situation and an approach of environmental management measure (EMM) model for sustainable solid waste management: case study of Dhaka city. $J$. of Environ. Sci. and Natural Resour.5(1):99-111.

19. Azad AK, Nahar A, Hasan MM, Islam K, Azim MF, Hossain MS, Rahman MR, Ojha RK, Mahmud GMS, Kayes R. 2013. Fermentation of municipal solid wastes by bacterial isolates for production of raw protein degrading proteases. Asian J. of Microbio. Biotechn. and Environ. Sci, 15: 365-374.

20. Sneath PH, Mair NS, Sharpe ME, Holt JG. 1986. Bergey's manual of systematic bacteriology. 2: Williams \& Wilkins.

21. Wood TM, Bhat KM. 1988. Methods for measuring cellulase activities. Meth. in enzymol.160:87-112.

22. Phadatare SU, Deshpande VV, Srinivasan MC. 1993. High activity alkaline protease from Conidiobolus coronatus (NCL 86.8. 20): Enzyme production and compatibility with commercial detergents. Enz. and Microbial Techn.15(1):72-76.

23. Hankin L, Anagnostakis SL. 1977. Solid media containing carboxymethylcellulose to detect Cx cellulase activity of microorganisms. J. of Gen. Microbio. 98(1):109-115.

24. Gautam S, Bundela P, Pandey A, Awasthi M, Sarsaiya S. 2010. Optimization of the medium for the production of cellulase by the Trichoderma viride using submerged fermentation. Intern. J. of Environ. Sci.1(4).

25. Silva-Santisteban BOY. 2005. Agitation, aeration and shear stress as key factors in inulinase production by Kluyveromyces marxianus. Enz. and Microbial Techn.36(5):717-724.

26. Domingues F, Queiroz J, Cabral J, Fonseca L. 2000. The influence of culture conditions on mycelial structure and cellulase production by Trichoderma reesei Rut C-30. Enz. and Microbial Techn.26(5):394401.

27. Bajaj BK, Pangotra H, Wani MA, Sharma P, Sharma A. 2009. Partial purification and characterization of a highly thermostable and $\mathrm{pH}$ stable endoglucanase from a newly isolated Bacillus strain M-9. Indian J. Chem. Technol.16:382-387.

28. da Silva LC, Honorato TL, Cavalcante RS, Franco TT, Rodrigues S. 2012. Effect of pH and temperature on enzyme activity of chitosanase produced under solid stated fermentation by Trichoderma spp. Indian J. of Microbio.52(1):60-65.

29. Immanuel G, Dhanusha R, Prema P, Palavesam A. 2006. Effect of different growth parameters on endoglucanase enzyme activity by bacteria isolated from coir retting effluents of estuarine environment. Intern. J. of Environ. Sci. and Techn..3(1):25-34.

30. Rahman M, Begum M, Khan M, Rahman M, Alam M. 2009. Isolation, Identification and cultural optimization of native bacterial isolates as a potential bioconversion agent. J. of Appl. Sci. Res.5(10).

31. Sozzi GO, Cascone O, Fraschina AA. 1996. Effect of a hightemperature stress on endo- $\beta$-mannanase and á-and â-galactosidase activities during tomato fruit ripening. Postharv. Biol. and Techn.9(1):49-63.

32. Gomes I, Gomes J, Steiner W, Esterbauer H. 1992. Production of cellulase and xylanase by a wild strain of Trichoderma viride. Appl. Microbio and Biotech.36(5):701-707.

33. Wang G, Zhang X, Wang L, Wang K, Peng F, Wang L. 2012. The activity and kinetic properties of cellulases in substrates containing metal ions and acid radicals. Adv. in Biolog. Chem.2:390. 